\title{
Mediating Role of Career Commitment in the Relationship of Promotional Opportunities, Rewards and Career Success
}

\author{
Ahmad Tisman Pasha \\ University Utara Malaysia (UUM) \\ atisman120@hotmail.com \\ Kamal Ab Hamid \\ Associate Professor, University Utara Malaysia \\ abkamal@uum.edu.my \\ Arfan Shahzad \\ Abdullah Graduate School of Business, University Utara Malaysia \\ arfan@uum.edu.my
}

\begin{abstract}
The objective of the study is to investigate the mediating role of career commitment between career development practices and career success of employee in insurance sector of Pakistan. Survey method was adopted to collect the data form 374 employees working in insurance sector systematic sampling. PLSSEM technique was used using Smart PLS 2.0 to analyze the data. Findings of the study suggests that employees' career development practices have positive relationship with career commitment and career success. Career commitment also have a positive relation with career success. Finally, career commitment mediates the positive role between career development practices and career of insurance sector employees. The effect of career development practices on career commitment and effect of career development practices on career success has been checked in past studies but the mediating role of career commitment particularly for the employees of insurance sector has not been checked before.
\end{abstract}

Keywords: Career success, Career Commitment, Promotional Opportunity and Rewards.

\section{Introduction}

Insurance sector is considered to be the long term business in European countries. In few years more than 90 studies on productivity measurement of insurance sector have been conducted in the US, Germany, France, Switzerland, Japan and particularly European countries but not on the individuals (employees) of the companies (Eling \& Luhnen, 2010). Relationship is found between insurance and economic development that how insurance sector of world is growing too fast as compared to under developing countries like Pakistan. In developing countries, still remain low in generating the insurance premium (Outreville, 2012).

It has been reported that there is huge number of unemployed people in Pakistan and yet the insurance sector has not been able to attract the attention of unemployed personal. Quite a reasons can be posed for this poor performance of insurance sector and people are not inclined towards insurance sector because of having no education, religious factors that insurance is considered prohibited, less understanding and lack of trust on the insurance personnel's and companies (Allen, Shore, \& Griffeth, 2003). 
The employees' career improvement becomes a cause of improvement in insurance sector employees also, and this helps not only the company but also in the development of professional career (Salanova, Llorens, Acosta, \& Torrente, 2013). According to (Okurame \& Balogun, 2005) the employees of the insurance companies need to be motivated incessantly to achieve higher levels of outcome that are needed not only for the insurance company, but also for the career of the employee.

A question of career success, career commitment or career opportunities is answerless without the mutual interaction between employees and organization (Kirkbesoglu \& Ozder, 2015). Employees want to find a path and explore career in insurance sector. Job security rewards, training, promotional opportunity, career strategies and development programs can manage the employee's career and it ensures the success factor in career (Yean \& Yahya, 2013). Promotional opportunity and reward system are the indicator of career success. According to (Armstrong \& Taylor, 2014), employee's career development factors are the assets of the organizations and these factors which are promotional opportunities and rewards are considered to be the foundation of employee's career success. Supporting career developments needs will ensure career success in any organization but particularly in insurance sector (Khilji \& Wang, 2007).

This research study suggests that organizational rewards and promotional opportunity are key career development practices. These career development practices play key role in term relationship for benefit of the employment and improving employee career commitment and career success by their stronger belief in insurance sector. The objective of this research paper to identify the relationship between promotional opportunities, rewards on the career success with the mediating role of career commitment in insurance sector of Pakistan.

\section{Literature Review}

In the existing literature, most of the studies focused on job-related issues such as job security, training, career views, equality and work issues (Armstrong \& Taylor, 2014), (Eddleston, Baldridge, \& Veiga, 2004), (Nabi, 2001) as predictors influencing employee career satisfaction. In the context to Pakistan, studies conducted on insurance sector but, especially none of these studies focused on career commitment and career success.

In this research study, career success is defined as dependent variable. Career success is focused as the outcome of employees' career experience (Arthur et al., 2005). Career success is the result of positive psychological and career related experiences in work (Judge et al., 1995, p. 486). Career success is dependent on the employees' career practices, contributions, achievements and commitments in the insurance sector. According to Chen, (2011) career success is the long term experiences of job.

Insurance sector is one of the highly neglected sectors as compared to the other sectors of the Pakistan (Haroon \& Mohamed, 2011). Insurance sector will not accomplish fast economic and social development unless the employees have required skills, attitude and goals to join it as career (Olson, 2008). 
Employees that have high levels of job fulfilment are more committed to their careers, through promotional opportunities and rewards (Maxwell, Ogden, \& Broadbridge, 2010). The skills development and career development opportunities are interrelated factors (Adeoye \& Fields, 2014). On the other hand, (Malik \& Ahmad Gujjar, Job Satisfaction: Evaluation of Statelife Insurance Corporation, 2012) strongly recommended that study should be conducted on employees' career success in insurance companies of Pakistan.

In attempt to explain this situation many researchers (Ugboro \& Obeng, 2015), (Creed \& Hood, 2014), (Penny Wan, Wong, \& Kong, 2014) among many others, confirms that the career commitment will affect the organizational performance. However, lower level of career commitment will affect the career success (Poynton, Lapan, \& Marcotte, 2015), (Arora \& Rangnekar, 2015). There are few reasons such as,

- Low level promotional opportunities will affect career commitment.

- No reward system will also affect the career commitment.

One of the latest study (Adeoye \& Fields, 2014) recommended that insurance companies should design and implement career development programs such as promotion plans and rewards for employees to be committed to their careers and get success in the insurance sector. On the other hand, (Barley, Stephen, \& K., 2001) stressed on the point that employee play key role in breaking or making of an organization. Both insurance and banking sector are considered as financial and service sectors but still insurance sector is the ignored by government, policies and religious views.

Promotional opportunity is one of the key independent variable of career development practices. Promotional opportunity is used to measure the outcomes of employees who work too hard in the insurance sector (Bilal, \& Ahmed, 2016). Promotional opportunity starts with job and get matured with career success (Russell, Broomé \& Prince, 2015). To achieve the highest level in career success, promotional opportunity influence insurance sector employees.

According to (Janjua \& Akmal, 2014) are of the opinion that insurance industry of Pakistan is neglected if we compare it other regional upcoming economies but at the same time it definitely has vast potential in it to grow into a huge and big industry.

The career commitment in service sectors was the major findings of many studies of individual's career thinking and work attitude (Maxwell, Ogden, \& Broadbridge, 2010).

Career development opportunity, promotion fairness and promotional opportunities have independently been shown to affect employees' commitment to their careers and the success that he or she has attained. External success elements in terms of number of promotions, rewards and other career development practices lead towards career success which strengthens employee view of their career (Nabi, 2001).

Awarding reward satisfies psychological needs of the employee and those who have reward incentives in their work they performed better than the people that did not have reward incentives in their work. This is also one of the factors that play role in career success 
H1: There is a significant relationship between promotional opportunity \& career commitment.

H2: There is a significant relationship between competitive rewards and career commitment.

H3: There is a significant relationship between promotional opportunity and career success.

H4: There is a significant relationship between competitive rewards and career success.

H5: Career Commitment is a mediator between promotional opportunities \& career success.

H6: Career Commitment is a mediator between rewards \& career success.

H7: There is a significant relationship between career commitment and career success.

\section{Theoretical Framework}

This research framework was designed to portray the variables integrated in this study trace their relationship to detect their influences on career success. This model shows the mediating relationship of career commitment between CDP (promotional opportunities and rewards) and career success.

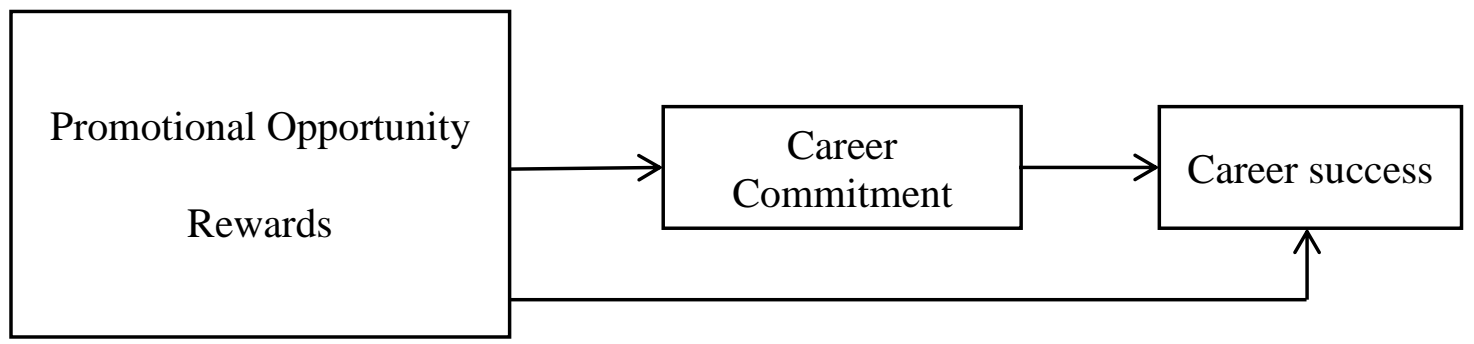

Figure 1: Theoretical framework of employees Career Development Practices, Career Commitment and Career Success

\section{Instrumentation}

Career development practices is focused upon classifying the need and exploring the level of career commitment of employees and its relationship with the career success. To measure the career development practices and its impact on career under the mediating role of career commitment, a total of 24 items were used, which were adopted from (Greenhaus, Parasuraman \& Wormley, 1990), (Kong, Cheung \& Song, 2012), (Adeniji, 2011) and (Gerald, 2011).

\section{Research Design}

The population for this study consists of all the employees in the insurance sector in Pakistan. According to the Insurance Book, Year 2013-2014 and (SBP, 2013), there are nearly 9,000 employees in total 35 insurance companies. Stratified sampling techniques was followed to collect the data from the respondents. For this purpose, the sampling frame will consist of all the employees of the insurance companies in Pakistan. The employees working in the insurance sector of Punjab, Sindh, KPK Pakistan will be the target population. 
The data have been collected using self-administered questionnaires. Paper and pencil method technique was employed to collect the responses form the respondents. For the purpose, total number of 650 questionnaires were distributed among the randomly selected employees from each stratum. Out of 650 questionnaires, 350 were distributed in the province Punjab, 200 in province Sindh and 100 in province KPK. Out of 650 distributed questionnaires, 386 questionnaires were returned back. Yielded response rate was $59.38 \%$. Efforts were made to increase the response rate by reminding respondents through phone calls, SMS and personal visits. 12 questionnaires were discarded due to incompleteness and response biasness. Hence, the effective response rate was $57.54 \%$.

\section{Sample Characteristics}

With all variables used in research, respondents were also asked to indicate the number of aspects related to job description, individual characteristics, education and gender of the employees working in the insurance sector of Pakistan. The descriptive analysis in Table 1 , revealed that $31.3 \%$ employees are working as managers in different insurance companies and $68.7 \%$ employees are working as sales \& marketing executive in insurance sector of Pakistan. This also indicates that most of the employees are related to sales and marketing job in the insurance sector. This analysis revealed that $81.3 \%$ males and only $18.7 \%$ females are working in the insurance sector of Pakistan. Only $3.5 \%$ of employees have completed matric or below in education, $9.6 \%$ have completed intermediate. $32.6 \%$ employees are graduate and $51.1 \%$ have completed their master level. This analysis also shows that $3.2 \%$ employees in insurance sector have completed higher education which is above than master level.

\section{Table 1: Summary of Respondents' Demography}

\begin{tabular}{lrr}
\hline Items & Frequency & Percentage \\
\hline Job Designation & & \\
Manager & 117 & 31.3 \\
SME & 257 & 68.7 \\
\hline Gender & & \\
Males & 304 & 81.3 \\
Females & 70 & 18.7 \\
\hline Education & & \\
$\quad$ Matric or below & 13 & 3.5 \\
Intermediate & 36 & 9.6 \\
Graduate & 122 & 32.6 \\
Master or above & 191 & 51.1 \\
Others & 12 & 3.2 \\
\hline
\end{tabular}

\section{Structural Equation Modeling}

The Structural Equation Modeling (SEM) is used to prove the hypotheses arising from the theoretical framework. In order to execute the SEM analysis, the two stage approach 
was adopted as it is suggested by Anderson and Gerbing (1988). First we discussed the measurement model among the latent variable, second we used the structure model to determining the causal relationships between the observed variables. For this purpose, confirmatory factor analysis we were used the SmartPLS 2.0. In the second stage, the paths or causal relationships between the underlying exogenous and endogenous constructs were specified in the structural model.

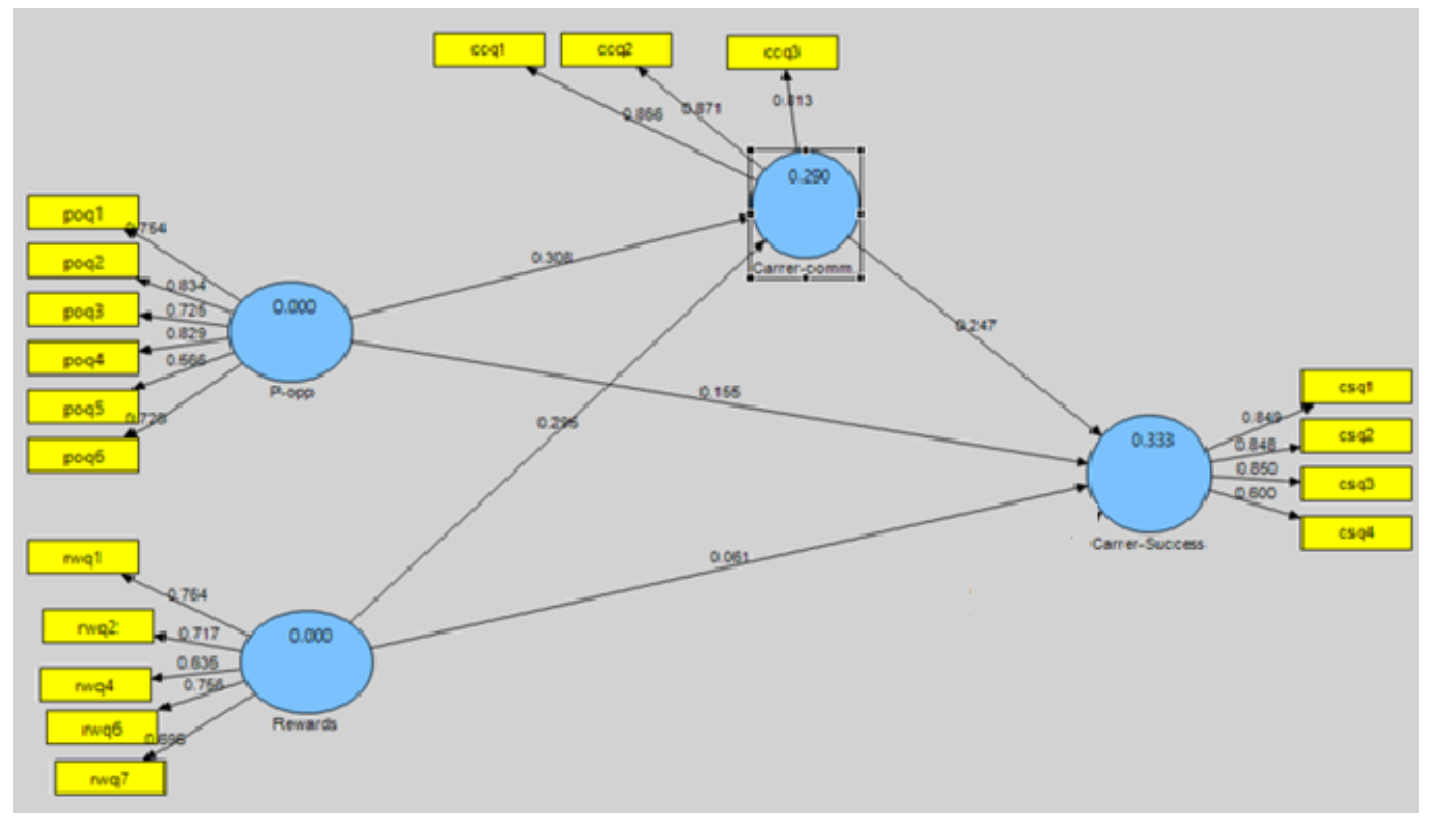

Figure 2: Measurement Model

\section{Content Validity}

According to Hair et al. (2010), the degree to which the variables (items) have the ability to measure a particular construct and how closely these items measure the concept for which they were designed to measure, reveals the content validity of construct. Table 2 provides an evidence of the content validity of the measures used. The evidence reveals that the items designed to measure/ assess a particular construct depicts evidence of having higher factor loadings on their respective constructs as compared to the other constructs. On the other hand, the items' significant loading on their respective constructs, validate the content validity of the constructs too.

Table 2: Factor Loading/ Cross Loading

\begin{tabular}{ccccc}
\hline & $\begin{array}{c}\text { Career- } \\
\text { commitment }\end{array}$ & $\begin{array}{c}\text { Career- } \\
\text { Success }\end{array}$ & PO & Rewards \\
\hline ccq1 & $\mathbf{0 . 8 6 6}$ & 0.399 & 0.421 & 0.391
\end{tabular}




\begin{tabular}{lllll} 
ccq2 & $\mathbf{0 . 8 7 1}$ & 0.452 & 0.407 & 0.427 \\
$\mathbf{c c q 3}$ & $\mathbf{0 . 8 1 3}$ & 0.362 & 0.406 & 0.403 \\
$\mathbf{c s q 1}$ & 0.415 & $\mathbf{0 . 8 6 2}$ & 0.363 & 0.360 \\
$\mathbf{c s q 2}$ & 0.389 & $\mathbf{0 . 8 2 6}$ & 0.355 & 0.315 \\
$\mathbf{c s q 3}$ & 0.420 & $\mathbf{0 . 8 8 3}$ & 0.404 & 0.355 \\
$\mathbf{c s q 4}$ & 0.253 & $\mathbf{0 . 6 0 0}$ & 0.208 & 0.184 \\
poq1 & 0.421 & 0.343 & $\mathbf{0 . 7 5 4}$ & 0.456 \\
poq2 & 0.406 & 0.362 & $\mathbf{0 . 8 3 3}$ & 0.531 \\
poq3 & 0.345 & 0.290 & $\mathbf{0 . 7 2 5}$ & 0.439 \\
poq4 & 0.399 & 0.351 & $\mathbf{0 . 8 2 9}$ & 0.468 \\
poq5 & 0.193 & 0.246 & $\mathbf{0 . 5 6 6}$ & 0.263 \\
poq6 & 0.342 & 0.333 & $\mathbf{0 . 7 2 6}$ & 0.449 \\
rwq1 & 0.393 & 0.345 & 0.455 & $\mathbf{0 . 7 6 5}$ \\
rwq2 & 0.254 & 0.252 & 0.416 & $\mathbf{0 . 7 1 5}$ \\
rwq4 & 0.318 & 0.207 & 0.421 & $\mathbf{0 . 6 3 4}$ \\
rwq6 & 0.342 & 0.265 & 0.421 & $\mathbf{0 . 7 5 7}$ \\
rwq7 & 0.375 & 0.327 & 0.411 & $\mathbf{0 . 6 9 6}$ \\
\hline
\end{tabular}

$\mathrm{CS}=$ Career Success, $\mathrm{CC}=$ Career Commitment $\mathrm{PO}=$ Promotional Opportunity, $\mathrm{R}=$ Rewards

The bold values in Table 2, indicates that the factor/ cross loadings exceed the suggested threshold of 0.50 or above showing satisfactory/ acceptable contribution of the indicators to assigned constructs. Additionally, as argued by Hair et al., (2013), discriminant validity can be assessed/ evaluated by examining the outer loadings of indictors. They also argue that discriminant validity can be shown when on a construct the outer loading of the indicators is higher than all its cross-loading with other constructs.

For the first time the PLS algorism was computed, there were some items that loaded extremely poor, for example, following items are not included in the PLS algorism, CCQ4 (question sequence \# 9), CCQ5 (question sequence \# 10), RWQ3 (question sequence \# 20) and RWQ5 (question sequence \# 22) because deletion of these items lead to increase in CR and AVE of all these constructs to the minimum acceptable values.

\section{Convergent Validity}

Table 3 depicts the dependent variable, the $\mathrm{CR}$ of career success is 0.870 and $\mathrm{CR}$ for independent variables $\mathrm{PO}$ and $\mathrm{R}$ is 0.880 and 0.839 respectively, while $\mathrm{CR}$ mediating variable CC is 0.887 respectively. The value of AVE greater than 0.5 for each construct is another evidence of convergent validity. The results in Table 3 shows that all constructs have an AVE greater than 0.5, indicating strong convergent validity. Similarly, to show convergent validity, all item loadings (outer loadings) should be greater than 0.6 (shown in Table 3) and according to (Bassellier \& Benbasat, 2004) suggests that more than half of the variance is captured by the constructs.

Table 3: Convergent Validity 


\begin{tabular}{|c|c|c|c|c|c|}
\hline Construct & Item & Loadings & Cronbach's Alpha & CR & AVE \\
\hline \multirow[t]{3}{*}{ Career Success } & ccq1 & 0.866 & 0.800 & 0.870 & 0.631 \\
\hline & ccq2 & 0.871 & & & \\
\hline & ccq3 & 0.813 & & & \\
\hline \multirow[t]{4}{*}{ Career commitment } & $\operatorname{csq} 1$ & 0.862 & 0.808 & 0.887 & 0.724 \\
\hline & $\operatorname{csq} 2$ & 0.826 & & & \\
\hline & $\operatorname{csq} 3$ & 0.883 & & & \\
\hline & $\operatorname{csq} 4$ & 0.600 & & & \\
\hline \multirow[t]{6}{*}{ Promotional Opportunity } & poq1 & 0.754 & 0.835 & 0.880 & 0.554 \\
\hline & poq2 & 0.833 & & & \\
\hline & poq3 & 0.725 & & & \\
\hline & poq4 & 0.829 & & & \\
\hline & poq5 & 0.566 & & & \\
\hline & poq6 & 0.726 & & & \\
\hline \multirow[t]{5}{*}{ Rewards } & rwq1 & 0.765 & 0.761 & 0.839 & 0.511 \\
\hline & rwq2 & 0.715 & & & \\
\hline & rwq4 & 0.634 & & & \\
\hline & rwq6 & 0.757 & & & \\
\hline & rwq7 & 0.696 & & & \\
\hline
\end{tabular}

\section{Discriminant Validity}

The most conventional approach in assessing/ evaluating discriminant validity considered is Fornell-Larcker criterion (Hair et al., 2013). Others criterion include cross-loading examination method, which is however, considered more liberal, since it is likely to have more constructs exhibiting discriminant validity. Therefore, discriminant validity was assessed for career commitment (CS), career success (CC), promotional opportunity (PO) and rewards $(\mathrm{R})$. Discriminant validity is established when the square root of value of AVE of each construct is higher than the highest correlation of the construct with any other latent construct. Fornell-Larcker Criterion results are shown Table 4 for assessment with the square root of the constructs. The square root of value of AVE (in bold) is greater than its highest correlation of construct with any other constructs. Thus, it is concluded that discriminant validity on the construct has been established, therefore, it is assumed that the results obtained relate to the hypotheses testing should be valid and reliable.

In Table 4, absence of discriminant validity indicates problem since the loadings are greater than 0.5 , and there is no any other indicator that has loading more than the one it intends to measure. 
Table 4: Discriminant Validity

\begin{tabular}{ccccc}
\hline & $\begin{array}{c}\text { Career- } \\
\text { Success }\end{array}$ & $\begin{array}{c}\text { Career- } \\
\text { commitment }\end{array}$ & PO & Rewards \\
\hline Career-Success & $\mathbf{0 . 7 9 4}$ & & & \\
Career-commitment & 0.474 & $\mathbf{0 . 8 5 1}$ & $\mathbf{0 . 7 4 4}$ & \\
PO & 0.430 & 0.483 & 0.594 & $\mathbf{0 . 7 1 5}$ \\
Rewards & 0.392 & 0.478 & \\
\hline
\end{tabular}

After getting a good result of the evaluation of the measurement model (outer model) precisely, the latent variables suggest satisfactory evidence of reliability and validity, the next step was evaluation of structural model (inner model). However, because the original framework is based on what is obtained in the existing literature, there is a need to revise and improve it since the outer model assessment has been conducted.

\section{Direct Relationships}

The evaluation of the structural model initiates with an examination of the direct relationships among the independent variables, mediator and the dependent variable. The path coefficients' size was examined through PLS-SEM Algorithm, and the significance of the relationship was examined through PLS-SEM bootstrapping procedure in the SmartPLS 2.0 software. The valid number of observation in data set was used as the number of cases, and 5,000 was used as number of bootstrapping samples.

In this model, first it is focused on the analysis of the direct relationship between the independent variables and the mediator variable ( $\mathrm{H} 1$ and $\mathrm{H} 2)$. In the second step, the relationship between the independent variables and the dependent variable is analyzed (H3 and H4). In the third step, the mediation of CC analysis took place, where $\mathrm{H} 7$ were examined between $\mathrm{CC}$ as independent variable and $\mathrm{CS}$ as dependent variable. In the fourth step, the significant relationship is examined between $\mathrm{CC}$ as mediator and CS as dependent variable as $\mathrm{H} 5$ and H6.

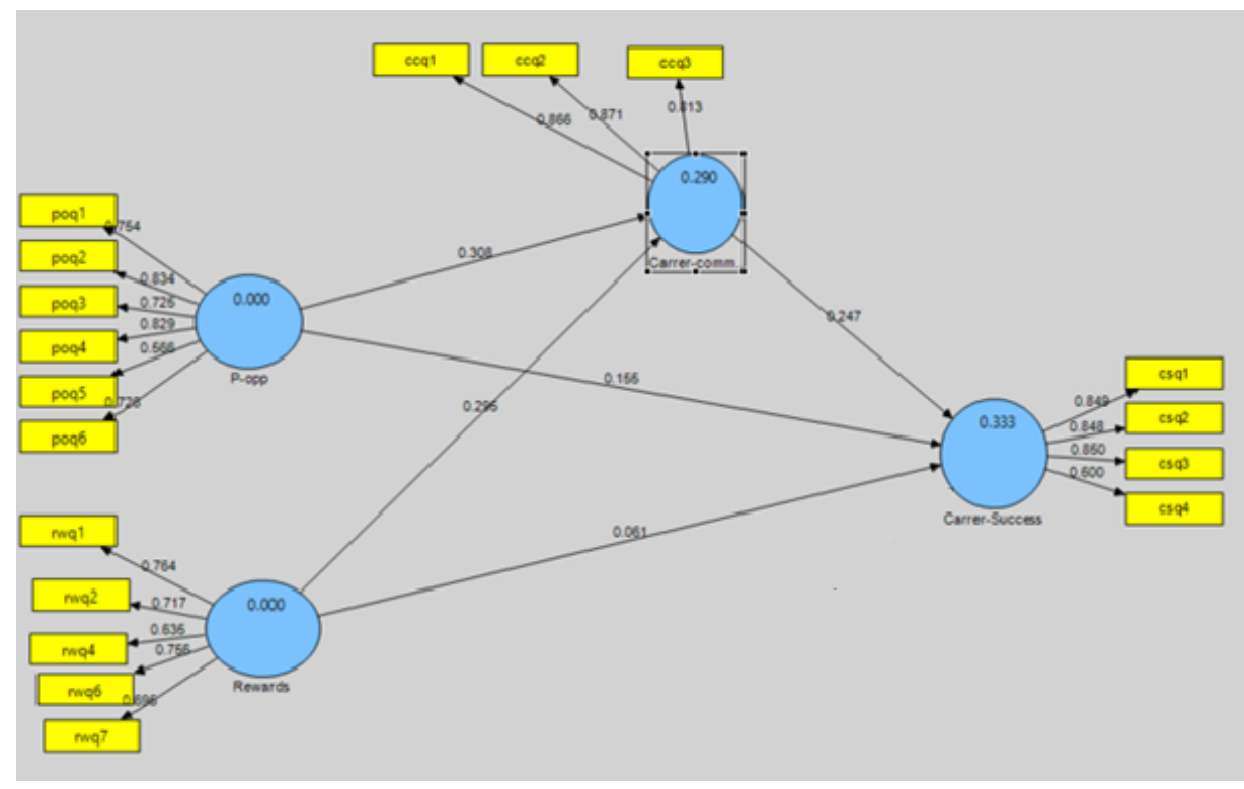

Figure 3: PLS Algorithm Direct Relationship 
Based on the PLS-SEM bootstrapping procedure as mentioned above, Figure 2 shows the path coefficient of independent and dependent variables. In Figure 3 shown that some the independent variables have a positive relationship with the dependent variables, such as the variable of Promotional opportunity and reward have positive significant relationship with career success; two of the independent variables are significant at $p<0.05$. It presents the results of the path coefficients, $t$-statistics and $p$-values.

With respect to $\mathrm{H} 1$, the result suggests that there is a positive impact of $\mathrm{PO}$ on $\mathrm{CC}$ $(\beta=0.308 ; t=5.146 ; p<0.000)$; therefore, $\mathrm{H} 1$ is supported. However, $\mathrm{H} 2$ is supported because the result shows significant influence of $\mathrm{R}$ on $\mathrm{CC}(\beta=0.295 ; t=$ 5.263; $p<0.000)$. About $\mathrm{H} 3$, the result shows a significant positive influence of $\mathrm{PO}$ on CS $(\beta=0.155 ; t=2.344 ; p<0.010)$; so H3 is also supported. H4 results shows nonsignificant influence of $\mathrm{R}$ on $\mathrm{CS}(\beta=0.061 ; t=1.050 ; p<0.147)$; so H4 is nonsupported. H7 results shows the significant positive impact of $\mathrm{CC}$ on $\mathrm{CS}(\beta=$ 0.247; $t=3.899 ; p<0.00$ ); so H7 is supported.

Table 5: Results of Hypotheses Testing (Direct Relationships)

\begin{tabular}{clccccc}
\hline NO & \multicolumn{1}{c}{ Hypothesized Path } & $\begin{array}{c}\text { Path } \\
\text { coefficient }\end{array}$ & $\begin{array}{c}\text { Standard } \\
\text { Error } \\
\text { (STERR) }\end{array}$ & T Value & P Value & Decision \\
\hline 1 & Career-commitment -> Career-Success & 0.247 & 0.063 & 3.899 & 0.000 & supported \\
2 & PO -> Career-Success & 0.155 & 0.066 & 2.344 & 0.010 & Supported \\
3 & PO -> Career-commitment & 0.308 & 0.060 & 5.146 & 0.000 & Supported \\
4 & R -> Career-Success & 0.061 & 0.059 & 1.050 & 0.147 & not-Supported \\
5 & R $>$ C Career-commitment & 0.295 & 0.056 & 5.263 & 0.000 & Supported \\
\hline
\end{tabular}

$* * *: \mathrm{P}<0.001 ; * *: \mathrm{P}<0.01, * \mathrm{P}<0.05$

The bootstrapping result found in Figure 2 shows that all the relationships are significant including the variable with a negative coefficient at $p<0.01$ and $p<0.05$ respectively. In addition, Table 5 presents the path coefficients, t-statistics and p-values.

\subsubsection{Mediation Test}

As mention before the mediation analysis took place in the model when the mediator variable was introduced. As shown below in Figure 4 the path coefficients of the four independent variables are positive. The path coefficients have a positive sign of all independent variables. Also, the path coefficient between the mediator and the dependent variable is also positive. The bootstrapping result found in Figure 4 shows all the relationships are significant and positive coefficient.

Mediation analysis assesses the indirect effect of the independent variable on the dependent variable via an intervening variable (Baron \& Kenny, 1986). According to Preacher and Hayes (2008), it was observed that there are number of methods for measuring mediation, which contain: Causal steps strategy or serial approach. Where the bootstrapping generates an empirical representation of the distribution of the sample of the indirect effect (Rucker, Preacher, Tormala, \& Petty, 2011). 


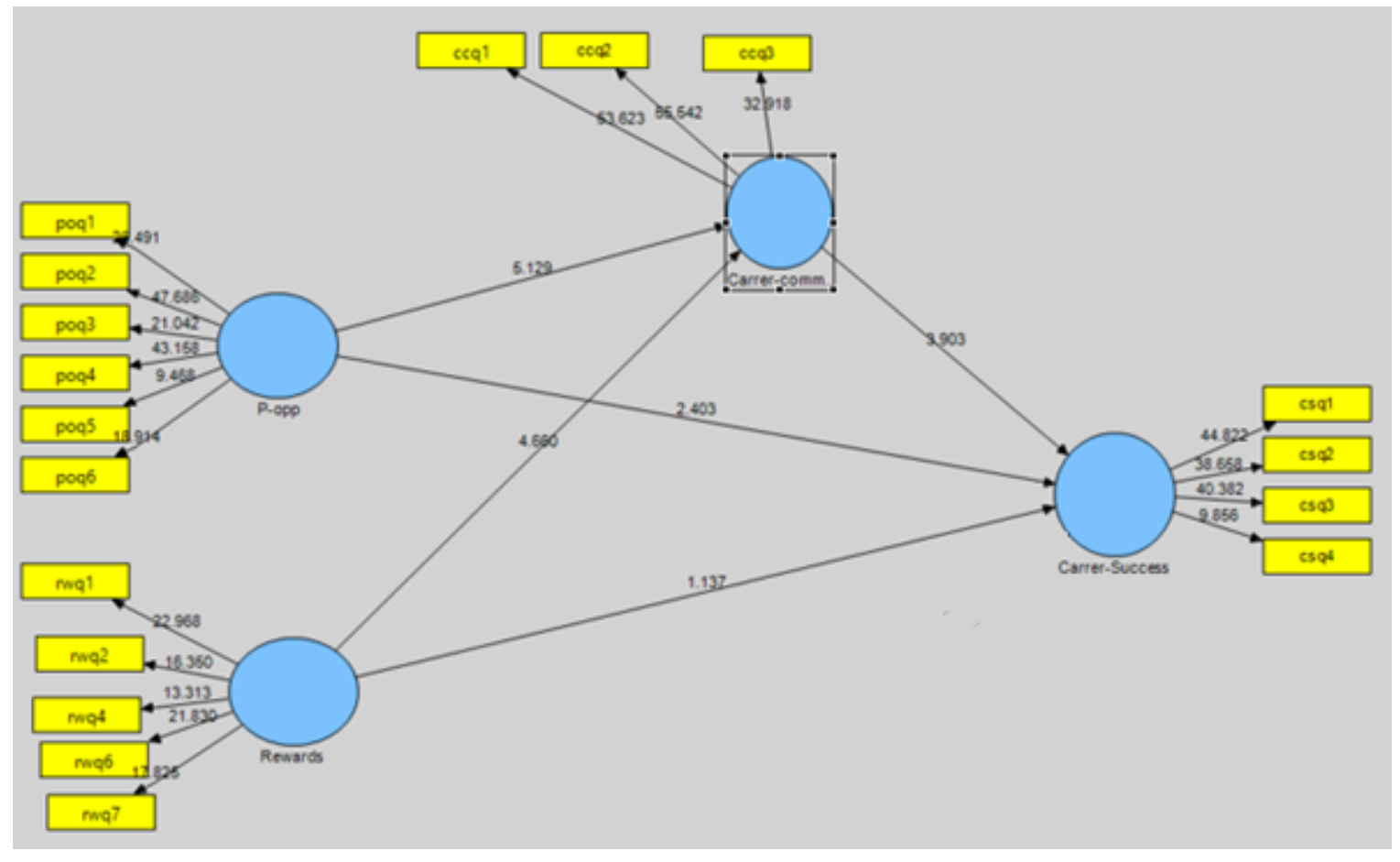

Figure 4: PLS-SEM Bootstrapping Indirect Relationship

After including the mediator construct, $\mathrm{CC}$ in model 2, the bootstrapping result of 5,000 samples were used to multiply path $a$ and path $b$. Then the product of the two significant paths was divided by the standard error of the product of the two paths $\frac{a \times b}{s_{a b}}$ to get the $\mathrm{t}$-value. From Table 6 , it is clear that $\mathrm{CC}$ mediates the positive relationship between PO and CS $(\beta=0.040 ; t=2.099)$, supporting H5. H6 shows the mediation result of $\mathrm{CC}$ between $\mathrm{R}$ and $\mathrm{CS}(\beta=0.047 ; t=1.824)$, not supporting H6 because there is no mediation. Results of the study shows that in the indirect effect of promotional opportunity and career success is significant having values of confidence interval $(\mathrm{LLCI}=0.003, \mathrm{ULCI}=0.077)$. Both lower level confidence interval $(\mathrm{LLCI})$ and upper level confidence interval (ULCI) are positive. Hence we conclude that the career commitment having the mediating role in the relationship of promotional opportunity and career success. In the indirect effect of rewards and career success, relationship is not significant because of positive and negative values (LLCI $=-0.004$, ULCI $=0.098$ ), so there is no mediation.

Table 6: Hypothesized Path Coefficients

Bootstrapped Confidence Interval

\begin{tabular}{lcccccccc}
\hline $\begin{array}{l}\text { Hypothesized } \\
\text { Path }\end{array}$ & Path a & Path b & $\begin{array}{c}\text { Indirect } \\
\text { Effect }\end{array}$ & SE & t-value & 95\% LL & 95\% UL & Decision \\
\hline PO->CC->CS & 0.169 & 0.236 & 0.040 & 0.019 & 2.099 & 0.003 & 0.077 & Mediation \\
R->CC->CS & 0.201 & 0.236 & 0.047 & 0.026 & 1.824 & -0.004 & 0.098 & No-Mediation \\
\hline
\end{tabular}

$* * *: P<0.001 ; * *: P<0.01, *: P<0.05$ 


\subsection{Conclusion}

We proposed an evolving process of career success and career commitment of working employees of insurance sector of Pakistan. Up till now, we have raised several important issues to consider career development practices of working employees of insurance sector of Pakistan. It has been discussed the major factors and variables which are important and have a positive impact and relation on the employees' career commitment and career success. The results and outcomes indicates a matter that career is a major function for employees but we have endeavored to explore that career development practices like promotional opportunity, rewards, and much more discussed about job security and training to build career commitment and career success of working employees of insurance sector.

There is a major distinction in it. These career development practices have a positive impact on career commitment and career success. It will be truly very helpful for the employees of insurance sector, first focus on their career by giving them career development opportunities to develop their career and career skills. Career development practices help them to be committed with their career in insurance sector and it will lead towards career success.

For real benefits and for potential employees and for the growth of insurance sector of Pakistan it is very important to implement career development practices, career commitment and career success of employees.

\section{References}

1. Adeniji, A. (2011). Organizational Climate and Job Satisfaction among Academic Staff in Some Selected Private Universities in Southwest Nigeria. Doctoral Dissertation, Covenant University.

2. Adeoye, A., \& Fields, Z. (2014). Compensation Management and Employee Job Satisfaction: A Case of Nigeria. Journal of Social Science, 41(3), 345--352.

3. Allen, D., Shore, L., \& Griffeth, R. (2003). The Role of Perceived Organizational Support and Supportive Human Resource Practices in the Turnover Process. Journal of Management, 29(1), 99--118.

4. Armstrong, M., \& Taylor, S. (2014). Armstrong's handbook of human resource management practice. Kogan Page Publishers.

5. Armstrong-Stassen, M., \& Cameron, S. (Career Development International). Factors related to the career satisfaction of older managerial and professional women. 10(3), 203--215.

6. Arora, R., \& Rangnekar, S. (2015). The Joint Effects of Personality and Supervisory Career Mentoring in Predicting Occupational Commitment. Career Dev Int., 20(1), 63--80.

7. Arthur, A. R. (2005). When stress is mental illness: A study of anxiety and depression in employees who use occupational stress counselling schemes. Stress and Health, 21(4), 273-280. 
8. Bassellier, G., \& Benbasat, I. (2004). Business competence of information technology professionals: Conceptual development and influence on IT-business partnerships. MIS quarterly, 673-694.

9. Baron, R. M., \& Kenny, D. A. (1986). The moderator-mediator variable distinction in social psychological research: Conceptual, strategic, and statistical considerations. Journal of personality and social psychology, 51(6), 1173.

10. Barley, Stephen, R., \& K., G. (2001). Bringing Work Back in. Organization Science, 12(1), 76--95.

11. Bilal, A., \& Ahmed, H. M. (2016). Organizational Structure as a Determinant of Job Burnout An Exploratory Study on Pakistani Pediatric Nurses. Workplace Health \& Safety, 2165079916662050.

12. Chen, C., \& Wen, P. (2016). The Effect of Mentoring on Protégés' Organizational Deviance. Psychological Reports, 119(1), 200-220.

13. Creed, P., \& Hood, M. (2014). The Development and Initial Validation of a Scale to Assess Career Goal Discrepancies. Journal of Career Assessment, 23(2), 308-317.

14. Eddleston, K. A., Baldridge, D. C., \& Veiga, J. F. (2004). Toward modeling the predictors of managerial career success: does gender matter? Journal of Managerial Psychology, 19(4), 360--385.

15. Eling, M., \& Luhnen, M. (2010). Efficiency in the International Insurance Industry: A Cross-Country Comparison. Journal of Banking \& Finance, 34(7), 1497--1509.

16. Gerbing, D. W., \& Anderson, J. C. (1988). An updated paradigm for scale development incorporating unidimensionality and its assessment. Journal of marketing research, 186-192.

17. Giannakis, D., \& Harker, M. (2014). Startegic Alignment between Relationship Marketing and Human resource Management in Financial Services Organizations. Journal of Strategic Marketing, 22(5), 396--419.

18. Greenhaus, J. H., Parasuraman, S., \& Wormley, W. M. (1990). Effects of race on organizational experiences, job performance evaluations, and career outcomes. Academy of management Journal, 33(1), 64-86.

19. Haiss, P., \& Sümegi, K. (2008). The relationship between insurance and economic growth in Europe: a theoretical and empirical analysis. Empirica, 35(4), 405--431.

20. Hair, J. F., Ringle, C. M., \& Sarstedt, M. (2011). PLS-SEM: Indeed a silver bullet. Journal of Marketing theory and Practice, 19(2), 139-152.

21. Haroon, M., \& Mohamed, N. (2011). Role of Private Investment in Economic Development of Pakistan. International Review of Business Research Paper, 7(1), 420--439.

22. Hoyle, R. H., \& Robinson, J. C. (2004). Mediated and moderated effects in social psychological research. Handbook of methods in social psychology, 213-233. 
23. Janjua, P., \& Akmal, M. (2014). A Comparative Analysis of Customers' Satisfaction for Conventional and Islamic Insurance Companies in Pakistan. International Journal of Economics and Finance, 6(4), 36-50.

24. Judge, T., Cable, D., Boudreau, J., \& Brets, R. (1995). An Empirical Investigation of the Predictors of Executive Career Success. Personnel Psychology, 48(3), 485-519 .

25. Kirkbesoglu, E., \& Ozder, E. (2015). The Effects of Organizational Performance on the Relationship between Perceived Organizational Support and Career Satisfaction: An Application on Insurance Industry. Jmr, 35.

26. Kong, H., Cheung, C., \& Song, H. (2012). Determinants and outcome of career competencies: Perspectives of hotel managers in China. International Journal of Hospitality Management, 31(3), 712-719.

27. Malik, H., \& Ahmad Gujjar, A. (2012). Job Satisfaction: Evaluation of Statelife Insurance Corporation. International Journal of Social Science and Education, 2(3), 519--530.

28. Maxwell, G. A., Ogden, S., \& Broadbridge, A. (2010). Generation Y's Career Expectations and Aspirations: Engagement in the Hospitality Industry. Journal of Hospitality and Tourism Management, 17(1), 53-61.

29. Nabi, G. (2001). The Relationship Between HRM, Social Support and Subjective Career Success among Men and Women. International Journal of Manpower, 22(5), 457--474.

30. Okurame, D., \& Balogun, S. (2005). Role of Informal Mentoring in the Career Success of First-Line Bank Managers. Career Development International, 10, $512--521$.

31. Olson, M. (2008). The Rise and Decline of Nations: Economic Growth, Stagflation, and Social Rigidities. Yale University Press.

32. Outreville, J. (2012). The Relationship between Insurance and Economic Development: 85 Empirical Papers for a Review of the Literature. Risk Management and Insurance Review, 16(1), 71--122.

33. Penny Wan, Y., Wong, I., \& Kong, W. (2014). Student Career Prospect and Industry Commitment: The Roles of Industry Attitude, Perceived Social Status, and Salary Expectations. Tourism Management, 40, 1--14.

34. Poynton, T., Lapan, R., \& Marcotte, A. (2015). Financial Planning Strategies of High School Seniors: Removing Barriers to Career Success. The Career Development Quarterly, 63(1), 57--73.

35. Preacher, K. J., \& Hayes, A. F. (2008). Asymptotic and resampling strategies for assessing and comparing indirect effects in multiple mediator models. Behavior Research Methods, 40(3), 879-891.

36. Rucker, D. D., Preacher, K. J., Tormala, Z. L., \& Petty, R. E. (2011). Mediation analysis in social psychology: Current practices and new recommendations. Social and Personality Psychology Compass, 5(6), 359-371. 
37. Russell, E. J., Broome, R. E., \& Prince, R. (2015). Discovering the Servant in Fire and Emergency Services Leaders: A Grounded Theory.

38. Salanova, M., Llorens, S., Acosta, H., \& Torrente, P. (2013). Positive Interventions in Organizations Positive Interventions in Positive Organizations. TERAPIA PSICOLOGICA, 31, 101--113.

39. SBP. (2013). Insurance Year Book 2013-2014.

40. Ugboro, I., \& Obeng, K. (2015). The Moderating Effects of Perceived Threat to Valued Job Features on Career Commitment Among University Professors. Australian Journal of Career Development, 24(1), 39--52.

41. Yang, F., \& Lau, V. (2015). Does Workplace Guanxi Matter to Hotel Career Success? International Journal of Hospitality Management, 47, 43--53.

42. Yean, T., \& Yahya, K. (2013). The Influence of Human Resource Management Practices and Career Strategy on Career Satisfaction of Insurance Agents. International Journal of Business and Society, 14(2). 